\title{
REVIEW ANALYSIS OF TALENT MANAGEMENT PRACTICES IN CONTEXT OF SME'S
}

\author{
Dr Pradhyuman Singh Lakhawat \\ Assistant Professor, \\ JSBS \& C, Shuats
}

\begin{abstract}
Talent management is really need of the hour, many of the MNC's are concentrating on better talent management practices to improve the organizational performances. Latest research studies are also indicating that proper talent management practices are directly related with the employee development, fair working environment, employee commitment and employee satisfaction. In the highly competitive era it is quite difficult to retain and manage the available manpower in such issues the better talent management practices can help. Present review study is based on the SME's and their talent management practices. In recent research studies it was found that high amount of manpower is engaged with the SME's and this segment also have significant contribution towards Indian economy also. Present study is revealed with various importance and approaches of talent management adopted by the SME's.
\end{abstract}

Key Words: Talent Management, SME's, Talent Acquisition, Talent Retention, Employee Satisfaction

\section{INTRODUCTION}

Talent means "the sum of person's natural ability to learn and grow.' The strategic importance of talent was appreciated after the study on McKinsey \& Co found that the most important corporate resource over the next 20 years will be talent: smart, sophisticated business people who are technologically literate, globally astute, and operationally agile. And even as the demand for talent goes up, the supply of it will be going down. Talent Management is managing the ability, competency and power of employees within an organization. The concept extends beyond recruiting the right candidate to exploring their hidden and unusual qualities and developing and nurturing them to the desired results. Hiring the best talent from the industry may be an important concern

\author{
Ms. Deeksha Singh \\ Scholar, \\ JSBS \& C, Shuats
}

for the organization today but retaining them and most importantly transitioning them according to the culture of the organization and getting the best output of them is a much bigger concern. Talent Management in organizations does a continuous process that involves sourcing, hiring, developing, retaining and promoting them while meeting the organizations requirement simultaneously. It is talent management that enables the organization in improving employee engagement, commitment, retention, value addition that is leading to improving organizational performance (Mohammed, 2015). On the other hand SME's- Small and Medium Enterprises. As we know SME's plays a very important role in the economic development or we can say that they are the backbone of the National Economy Structure if we go through the history. Currently, around 36 million SMEs are generating 80 million employment opportunities, contributing $8 \%$ of GDP, $45 \%$ of total manufacturing output and $40 \%$ of the total exports from the country. MSMEs account for more than $80 \%$ of the total industrial enterprises in India creating more than 8000 value added products. According to the Sixth Economic Census, conducted by the Central Statistics Office (Report of 6 Economic Census, 2013), 58.5 million establishments were found to be in operation. 34.8 million Establishments (59.48\%) were found in rural areas and nearby 23.7 million establishments (40.52\%) were found to be located in urban areas. MSME sector help to realize the target of proposed National Manufacturing Policy of raising the share of manufacturing sector in GDP from $16 \%$ at present to $25 \%$ by the end of 2022. Six Economic Censuses have been conducted so far in 1997, 1980, 1990, 1998, 2005 and 2013-14. SMEs in India faces a number of problems- absence of adequate and timely banking finance, non availability of suitable technology, ineffective marketing due to limited resources and non availability of skilled manpower (Mathiraj, Saroja Devi, Balasundari, 2018). Recently, Finance Minister Arun Jaitley launched a portal to 


\section{International Journal of Engineering Applied Sciences and Technology, 2019 \\ Vol. 4, Issue 5, ISSN No. 2455-2143, Pages 302-310 \\ Published Online September 2019 in IJEAST (http://www.ijeast.com)}

enable micro, small and medium enterprises (MSMEs) to get in-principle approval of loans within an hour without the need for a branch visit. The web portal, psbloansin59minutes, will enable in-principle nod for loans up to Rs 10 million within 59 minutes for MSMEs. The portal is for securing loan approvals only from Small Industries Development Bank of India, and five public sector banks (PSB) - State Bank of India (SBI), Bank of Baroda, Punjab National Bank, Vijaya Bank, and Indian Bank.

Small and Medium Enterprises contribution towards the economy is very effective. As we know at the time when we get independence, these SMEs help us to and grow day by day. Because of these SMEs we survived. To understand the role of SMEs we can remind the time of Barter System. The time when people used to exchanged services and goods for other services and goods in return. Today, this Barter System is replaced by techniques that are more sophisticated to aid in trading. At the back $600 \mathrm{BC}$ we can see the contribution of SMEs. Other than this in today's scenario also they plays an important role. They also play a very important in the success of Large Enterprises or MNCs. We can take the example of any Car Industry. Is that industry making every single part that involved in the car manufacturing process? There are many parts that are important for car manufacturing is done by the SMEs. Those Large Enterprises maintains a permanent deal with the some of SMEs and we do not even know their names. So, the Talent Management practices are very important in SMEs. If these practices are held by SMEs seriously that help them to grow faster and this results in the growth of the economy. As because of these SMEs, there are so many young men who get job and also they can start their own venture. That is why by developing this Talent Management practices provide in SMEs, then it will help them to achieve their goal and they can work more efficiently and effectively. The logic behind talent management is based on the fact that businesses are run by people. Processes, technology and capital are important but it is people who make the decisions. It's people who create value by using these corporate assets to create products an organization has, the better it will perform. This is the rationale behind talent management to attract, develop and utilize the brains to get superior business results.

\section{IMPORTANCE OF TALENT MANAGEMENT IN SME'S}

\begin{abstract}
a. Find Ideal Professionals For The Right Roles. You will ensure you have the ideal professionals performing at the right roles. When you take a gander at relationship building talent and qualities, you'll see a best fit for every job. Talent mapping is utilized in talent management and it enables you to analyze and capitalize on the potential in and around your organization. This impacts in both expanded profit margins and overall employment fulfillment.
\end{abstract}

b. Impassion Your Staff. The strategy will enable and impassion your staff. On the off chance that you see staff essentially as a number, you do understand that they know this! Then again, if you value them, provide resources for them and their future, and they will work for more potential mutual benefit for the organization as opposed to simply their paycheck.

c. Empower Performance Consistency. You'll empower performance consistency from your staff (particularly important with the more youthful age). Individuals are more inclined to operate within established hierarchies when they understand where they are needed and where they might be headed. Not only does talent management provide this level of clarity, the procedure allows professionals to capitalize on the phenomenon. It helps the professional to look ahead and focus on performance and growth.

d. Distinguish And Close Hierarchical Talent Gaps. You'll close hierarchical talent gaps by distinguishing them and making clear moves in altering the situation. The performance contrast between skilled individuals and those with less talent is immense with regard to results. Employees and how they are managed is the most vital wellspring of most productive and effective skills and qualities.

e. Retain Already Present And Recently Hired Top Talent. You will have a superior shot of retaining the top talent already present and recently hired as time goes on. Be careful with losing your best staff to your competitors! The emphasis ought to be on employee development projects and techniques to create and draw in high impact workers, and in the same vein, keeping quality professionals satisfied and effective. 


\section{International Journal of Engineering Applied Sciences and Technology, 2019 \\ Vol. 4, Issue 5, ISSN No. 2455-2143, Pages 302-310 \\ Published Online September 2019 in IJEAST (http://www.ijeast.com)}

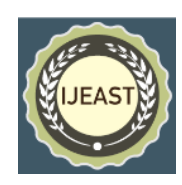

\begin{abstract}
f. Aim for Fewer Hiring-Related Errors During The Recruitment Process. There will be fewer hiring-related errors in the recruitment process. The nature of an organization is, basically, the nature of the staff it has. Numerous talent programs perform and execute employing assessments as a major aspect of the hiring and selection process. Analysis of their experience, skills and potential through modern systems and how they might factor into the company's hierarchy must be a critical step requiring comprehensive understanding of the situation.
\end{abstract}

g. Better Understanding Of The Workforce. Management will understand the workforce better than it did before. Employee reviews give extraordinary bits of knowledge about the professionals within the organizations. This aids in planning promotion structures as you will comprehend their requirements, profession goals and qualities and shortcomings of the potential candidates and how this might be remedied. By its nature, it is both diagnostic and curative. Thus, it is able to effectively form a professional development program that fulfills the needs of the organization as well as aligning with the company's long-term vision.

h. Make Employees Feel Valued And Motivated. Employees will begin to feel valued and along these lines be increasingly motivated at the workplace. Having a solid talent management culture determines how productive your workforce is and how invested they are in the business environments of your organization. There is no amount of decision making that can substitute this fundamental part of excellence and it gives organizations opportunities to make the most of exactly that.

i. Build Trust In Your Organization. The workforce will begin to build greater trust in your organization and its objectives. In the event that representatives are certain about talent management practices of the organization, they are bound to trust the vision of the organization. The outcome is a workforce that is locked in, dedicated and resolved to do what is best for your organization's success. This fact makes it too important to look over, and having the right people under your wing can make all the difference in the world.

\section{AIMS OF TALENT MANAGEMENT IN SMES}

1. To identify the reasons that why the talent programmers' are vital in an organization.

2. Frame the results preferred from talent management.

3. Help employees to use their full competence and potential.

4. To persuade employees to use finest of their efforts to achieve the organizational goal.

5. To create an environment to hoist the level of hidden creativeness and energy.

6. To create an organized work stipulation that domino effect into innovation, teamwork and the quality concept.

7. It maintains the suppleness in the organization which helps in erudition for the employees.

8. To prepare the personage for their future that also helps to attain organizational goal.

\section{STRATEGIES ADOPTED BY SME'S FOR RETAINING THE TALENT}

a. Recruitment: Constant recruitment of the right people with right talent who are fit for the job.

b. Talent Mapping: Deciding what kind of talent is required to fulfill the needs of the business. Identify the talent gap and fill them.

c. Workforce planning and development: Filling in the gap between the current state and the future state.

d. Performance planning and evaluation: Evaluate the performance of every employee and plan the future as per that.

e. Retention: Use of retention strategies can be made in order to keep the talent of the company with the company.

\section{ROLE OF SME'S IN INDIAN ECONOMY}

The Micro, Small and Medium Enterprises (MSMEs) have been contributing significantly to the expansion of entrepreneurial Endeavour's through business innovations. The MSMEs are widening their domain across sectors of the economy, producing diverse range of products and services to meet demands of domestic as well as global markets. 


\section{International Journal of Engineering Applied Sciences and Technology, 2019 \\ Vol. 4, Issue 5, ISSN No. 2455-2143, Pages 302-310 \\ Published Online September 2019 in IJEAST (http://www.ijeast.com)}

Table: Contribution of MSMEs

\begin{tabular}{|c|c|c|c|c|c|c|}
\hline Year & MSME GVA & Growth & Total GVA & $\begin{array}{l}\text { Share of } \\
\text { MSME in } \\
\text { GVA (\%) }\end{array}$ & Total GDP & $\begin{array}{l}\text { Share } \\
\text { MSME } \\
\text { GDP (\%) }\end{array}$ \\
\hline $2011-12$ & 2583263 & - & 8106946 & 31.86 & 8736329 & 29.57 \\
in \\
\hline $2012-13$ & 2977623 & 15.27 & 9202692 & 32.36 & 9944013 & 29.94 \\
\hline $2013-14$ & 3343009 & 12.27 & 10363153 & 32.26 & 11233522 & 29.76 \\
\hline $2014-15$ & 3658196 & 9.43 & 11481794 & 31.86 & 12445128 & 29.39 \\
\hline $2015-16$ & 3936788 & 7.62 & 12458642 & 31.60 & 13682035 & 28.77 \\
\hline
\end{tabular}

Source: Central Statistics Office (CSO), Ministry of Statistics \& Program Implementation

\section{ESTIMATED NUMBER OF SMES}

As per the National Sample Survey (NSS) 73rd round, conducted by National Sample Survey Office, Ministry of Statistics \& Program Implementation during the period 2015-16, there were 633.88 lakh unincorporated non-agriculture MSMEs in the country engaged in different economic activities
(196.64 lakh in Manufacturing, 230.35 lakh in Trade and 206.84 lakh in Other services and 0.03 lakh in non-captive Electricity Generation and Transmission,) excluding the MSME registered under (a) Section $2 \mathrm{~m}$ (i) and $2 \mathrm{~m}$ (ii) of the Factories Act, 1948, (b) Companies Act, 1956 and (c) Construction activities falling under section $\mathrm{F}$ of Nation Industrial Classification (NIC) 2008.

\begin{tabular}{|l|c|c|c|c|}
\hline \multirow{3}{*}{\begin{tabular}{l} 
Category \\
\multirow{2}{*}{ Activity }
\end{tabular}} & \multicolumn{2}{|c|}{ Estimated number of Enterprises (in lakh) } & Share (\%) \\
\cline { 2 - 5 } & Rural & Urban & Total & \\
\hline Manufacturing & 114.14 & 82.50 & $\mathbf{1 9 6 . 6 5}$ & 31 \\
\hline Trade & 108.71 & 121.64 & $\mathbf{2 3 0 . 3 5}$ & 36 \\
\hline Other Services & 102.00 & 104.85 & $\mathbf{2 0 6 . 8 5}$ & 33 \\
\hline Electricity* & 0.03 & 0.01 & $\mathbf{0 . 0 3}$ & 0 \\
\hline All & $\mathbf{3 2 4 . 8 8}$ & $\mathbf{3 0 9 . 0 0}$ & $\mathbf{6 3 3 . 8 8}$ & $\mathbf{1 0 0}$ \\
\hline
\end{tabular}

*Non-captive electricity generation and transmission and distribution by units not registered with the Central Electricity Authority (CEA) 


\section{International Journal of Engineering Applied Sciences and Technology, 2019 \\ Vol. 4, Issue 5, ISSN No. 2455-2143, Pages 302-310 \\ Published Online September 2019 in IJEAST (http://www.ijeast.com)}

\section{EMPLOYMENT}

It is seen that $31 \%$ MSMEs were found to be engaged in manufacturing activities, while $36 \%$ were in Trade and $33 \%$ in Other Services, again out of 633.88 estimated numbers of MSMEs, 324.88 lakh MSMEs $(51.25 \%)$ were in rural area and 309 lakh MSMEs $(48.75 \%)$ were in the urban areas.

Table: Estimated Employment in MSME Sector
As per the National Sample Survey (NSS) 73rd round conducted during the period 2015-16, MSME sector has been creating 11.10 crore jobs (360.41 lakh in Manufacturing, 387.18 lakh in Trade and 362.82 lakh in Other Services and 0.07 lakh in Non-captive Electricity Generation and Transmission) in the rural and the urban areas across the country.

\begin{tabular}{|l|c|c|c|c|}
\hline \multirow{2}{*}{$\begin{array}{c}\text { Broad Activity } \\
\text { Category }\end{array}$} & \multicolumn{3}{|c|}{ Employment (in lakh) } & Share (\%) \\
& Rural & Urban & Total & \\
\cline { 2 - 5 } & 186.56 & 173.86 & 360.41 & 32 \\
\hline Manufacturing & 160.64 & 226.54 & 387.18 & $\mathbf{3 5}$ \\
\hline Trade & 150.53 & 211.69 & 362.22 & $\mathbf{3 3}$ \\
\hline Other Services & 0.06 & 0.02 & 0.07 & $\mathbf{0}$ \\
\hline Electricity* & $\mathbf{4 9 7 . 7 8}$ & $\mathbf{6 2 1 . 1 0}$ & $\mathbf{1 1 0 9 . 8 9}$ & $\mathbf{1 0 0}$ \\
\hline All & & & & \\
\hline
\end{tabular}

*Non-captive electricity generation and transmission

Micro sector with 630.52 lakh estimated enterprises provides employment to 1076.19 lakh persons, which accounts for around $97 \%$ of total employment in the sector. Small sector with 3.31 lakh and medium sector with 0.05 lakh estimated MSMEs provides employment to 31.95 lakh $(2.88 \%)$ and 1.75 lakh $(0.16 \%)$ persons of total employment in MSME sector, respectively.

\section{STATE-WISE DISTRIBUTION OF ESTIMATED MSMES}

State of Uttar Pradesh had the largest number of estimated MSMEs with a share of $14.20 \%$ of MSMEs in the country. West Bengal comes as close second with a share of $14 \%$ again. The top 10 States together accounted for a share of $74.05 \%$ of the total estimated number of MSMEs in the country.

\begin{tabular}{|c|c|c|c|}
\hline \multirow{2}{*}{ SI No. } & \multirow{2}{*}{ State/UT } & \multicolumn{2}{|c|}{ Estimated Number of MSMEs } \\
\hline & & Number (in lakh) & Share (in \%) \\
\hline 1 & Uttar Pradesh & 89.99 & 14 \\
\hline 2 & West Bengal & 88.67 & 14 \\
\hline 3 & Tamil Nadu & 49.48 & 8 \\
\hline 4 & Maharashtra & 47.78 & 8 \\
\hline 5 & Karnataka & 38.34 & 6 \\
\hline 6 & Bihar & 34.46 & 5 \\
\hline 7 & Andhra Pradesh & 33.87 & 5 \\
\hline 8 & Gujarat & 33.16 & 5 \\
\hline
\end{tabular}




\section{International Journal of Engineering Applied Sciences and Technology, 2019 \\ Vol. 4, Issue 5, ISSN No. 2455-2143, Pages 302-310 \\ Published Online September 2019 in IJEAST (http://www.ijeast.com)}

\begin{tabular}{|c|l|c|c|}
\hline $\mathbf{9}$ & Rajasthan & 26.87 & 4 \\
\hline $\mathbf{1 0}$ & Madhya Pradesh & 26.74 & 4 \\
\hline & Total of above ten states & $\mathbf{4 6 9 . 3 6}$ & $\mathbf{7 4}$ \\
\hline & Other State/UTs & $\mathbf{1 6 4 . 2}$ & $\mathbf{2 6}$ \\
\hline & All & $\mathbf{6 3 3 . 8 8}$ & $\mathbf{1 0 0}$ \\
\hline
\end{tabular}

\section{GOVERNMENT POLICIES TOWARDS SMALL BUSINESS}

Government has divided these into three sections:

1. Protective measures

2. Promotional measures

3. Institutional measures

Realizing the important role of small businesses, the government has taken a number of measures to solve their problems and also how their growth encourages. The various measures initiated by government under the industrial policies issued from time to time.

\section{PROTECTIVE MEASURES:}

Such measures lead to protect the small scale industries from competition by large scale industries. They are as follows:

1. Reservation of 830 items for the exclusive production for small scale sectors. The large scale enterprises can not undertake the production of these items.

2. Giving concession like excise duty sale tax to the small scale industry, so that they can compete with big industry.

3. Preferences by government department in the purchase of items produced by small scale sector.

\section{PROMOTIONAL MEASURES:}

These measures are aimed for promotion of small scale industries. These include:

1. Supply of scare raw material to the small scale units at reasonable price and setting up of raw material deposed for quick supply of such material to the small scale units.

2. Setting up of common testing facility centre for benefit of cluster of groups of small scale units situation in a particular region.

3. Assistance by state small scale industries development corporations in securing orders from government department.

4. Preferences in land allocation and power connection to the small scale units and also provisions of power concession rates.

5. Setting up of industrial state and provision of industrial shed to enterprises on industrial basis.

6. Provision of technology assistance to small units by central small industries organizations is modernizing their technology of production.

7. Provision of concessional finance through commercial banks and other financial institutions like National Small Industries Corporation and State Financial Corporation. Small Industries Development Bank of India has been set up to provide financial existence to small scale units and refinancing facilities to the commercial banks against their landing to the small scale industries.

\section{INSTITUTIONAL MEASURES:}

The government has set-up the following institution for the benefit of small scale industry.

1. Small Scale Development Organization to provide training and other services to small scale sector.

2. National Small Industries Corporation (NSIC) to supply machinery on higher purchase basis, to arrange scare raw material and to provide marketing facilities.

3. District Industrial Centre in all districts to serve as a focal point of development for small scale and cottage industry.

4. Khadi and Village Industries Commission (KVIC) for encouraging production and marketing of khadi and handicraft items.

5. All India Boards such as Central Silk Board and Coir Board to provide technologies, financial and marketing facilities.

6. Small Industries Development Fund and Small Industries Development Bank of India for providing financial assistance to Small 


\section{International Journal of Engineering Applied Sciences and Technology, 2019 Vol. 4, Issue 5, ISSN No. 2455-2143, Pages 302-310 \\ Published Online September 2019 in IJEAST (http://www.ijeast.com)}

Scale Industries Funds are made available for marketing mix and working capital requirement and for updating technology.

7. Industrial State (about or more than 700 in semi-urban and rural areas) to provide infrastructure for growth of small scale industry.

\section{AVAILABLE LATEST RESEARCHES ON TALENT MANAGEMENT PRACTICES}

Hituand Baroda (2018) the result of this study illustrated that talent management practices have direct impact on employee motivation, employee satisfaction, employee creativity, and employee development and employee competency in the selected banks. While Altindăg, Çirakand Acar (2018) according to the findings obtained from correlation and regression analyses, a systematic structure that can reveal the talents of employees, and especially managers, increases employee satisfaction and employee performance. And; Satpathy, SailajaRani, Nagajyothi (2017) Small and Medium Enterprises (SMEs) is a key to economic development by its remarkable contribution in manufacturing output, employment, export, rural industrialization and, providing goods \& services at affordable costs by offering innovative solutions and sustainable development to the economy as a whole. If the policy maker will realize the potential of this sector and show their interest and initiation to set up new strategies for the up gradation of this sector then surely MSMEs will be able to the emerging challenges of a globally competitive order. In the same series Chungand Annunzio Green(2017) Said that, Talent can be "heavily disguised", so to some entrepreneurs it is about making talent realize that they are talented. The idea that stars are people who emerge over time reshapes what constitutes talent and the way in which one develops potential.

Kathiravan, Saikumar V, Sunitha (2017), revealed with that any form of business organization talent management is very essential. There searcher has found out the factors such as organization culture, career management, reward system, working environment and Business Strategy are vital for designing an effective talent management process. The talent management process strongly influence the job satisfaction, developing talent workforce, employee motivation and their commitment towards the corporate profit and customer satisfaction, which in turn will result in achieving the business goal using the PLS model fitting. And Sheokand and Verma (2015) found that the talent management concept is emerging slowly in today's scenario. The human resource also called as human capital of the organizations serve as the most important component of achieving competitive edge and now, the organizations that function at a global level have started to realize their value and importance. Tusang and Tajuddin (2015), In order to remain competitive, the management of SMEs need to put more attention on the implementation of talent management practices which contribute to organization performance. As mentioned by Malaysian Human Resource Minister, Datuk Dr. S. Subramaniam, which said that, SMEs should pay more attention to the factors of human resource particularly the skillful workforce in improving their productivity as well as maintaining the existing talent. Egerová, Lančarič, Eger, Savov (2015), the survey clearly indicates that talent management is not of primary concern for most organizations and remains in its infancy. Another major finding is that the size of an enterprise is a relevant determinant of its approach to and implementation of talent management. Amiri (2015), every employee has some talent. Many times management is never aware about his talent and how to utilize the employee's talent for the development and achieving the objectives of organization. It is the responsibility of management to identify the talented areas of employees as every employee has the hidden talent. If the management recognize and become aware about the talents of their employees and accordingly make a record of that and impart training for enhancing and utilizing the talent for the organization which will not only save the money but also the employees feel how important they are in the organization.

\section{CONCLUSION}

Talent management system is an effective and systematic approach to maintain and retain the existing talent in the organization (Lakhawat, 2016). There are many researchers who identified talent management as an important tool for employee satisfaction also. To maintain the talent within the organization there are many ways like career advancement, training and development, motivation, fair remuneration system and non-biased leader's 


\section{International Journal of Engineering Applied Sciences and Technology, 2019 Vol. 4, Issue 5, ISSN No. 2455-2143, Pages 302-310 \\ Published Online September 2019 in IJEAST (http://www.ijeast.com)}

behavior (Baroda, 2018). SME's are the future of Indian economy, because most of manpower like skilled, semi-skilled or un-skilled is engaged in various small and medium enterprises and contributing to the nation's economy.

\section{REFERENCES}

[1]. Ahmadi, P. (2012). Talent Management and Succession Planning. Interdisciplinary Journal of Contemporary Research in Business, 4, (Pg. 213224).

[2]. Anupam Rani, U. J. (2012). A Study of Talent Management as a Strategic Tool for the Organization in Selected Indian IT Companies. European Journal of Business and Management, 4, (pg. 20-28).

[3]. Bhatnagar, J. (2007). Talent management strategy of employee engagement in Indian ITES employees: key to retention. Employee Relations, 29, (pg. 640-663).

[4]. Chandrakanta Sahoo, V. P. (2010). Talent Management: Issues and Strategies. IOSR Journal of Business and Management, (pg. 29-34).

[5]. Chris Ashton, L. M. (2005). Managing talent for competitive advantage: Taking a systemic approach to talent management. Strategic HR Review, 4 (5), (pg. $28-31$ ).

[6]. David G Collings, K. M. (2009). Strategic Talent Management: A Review and Research Agenda. Human Resource Management Review , (pg. 304313).

[7]. David M. Gichuhi, R. W. (2014). Talent Management; It's role on competitiveness of public universities in Kenya. IOSR Journal Of Humanities And Social Science, 19 (1), (pg. 100-105).

[8]. Dehkordy, H. I. (2014). Study of factors affecting on talent management among Bank ${ }^{\text {ee }}$ s employees in Shahrekord. International Journal of Scientific Research, 8 (2), (pg. 1-10).

[9]. Elaine Farndale, H. S. (2010). The role of the corporate HR function in global talent management. Journal of World Business , (pg. 161-168).

[10]. K. Janardhanam, N. M. (2011). Talent Management Practices in IT sector. International Journal of Research in Commerce, IT and Management, 1 (2) (pg. 162-172).

[11]. Kamil, H. H. (2011). A study on the implementation of talent management practices at Malaysian Companies. Asian Journal of Business and Management Sciences, 1, (pg. 147-162).

[12]. Kaur, R. (2013). Empirical Study of Talent Management Program and Its Impact on the
Employee ${ }^{e c}$ s Retainment and Performance in Indian Supermarket Big Bazaar. Human Resource Management Research, (pg. 61-70).

[13]. Kavya Singh, S. S. (2012). Driving Forces and Emerging Challenges in Talent Management: A pathway to Organizational Success. International Journal of Advanced Research in Computer Science and Software Engineering, 2 (6), (pg. 117-121).

[14]. Kehinde, J. S. (2012). Talent Management: Effect on Organizational Performance. Journal of Management Research, 4, (pg. 178-186).

[15]. Layla Ataee Khoram, A. S. (2013). Relationship of Talent Management and Organizational Creativity in Maskan Bank of Hamedan. Middle-East Journal of Scientific Research , (pg. 728-731).

[16]. lyria, R. K. (2013). Role of Talent Management on Organization Performance in Companies listed in Nairobi security exchange in Kenya. International Journal of Humanities and Social Science, 3, (pg. 285-290).

[17]. R. V. Dhanalakshmi, K. B. (2014). A study on Talent management as a strategy to influence employee engagement and its effect on the organizational outcome. International Journal of Business and Administration Research Review, 2 (4), (Pg. 183-186).

[18]. Rita Kagwiria lyria, G. N. (2014). Effect of talent retention on organization performance in companies listed in Nairobi security exchange in Kenya. European Journal of Business and Social Sciences, 3, (pg. 47-58).

[19]. Sakineh haghparast, M. M. (2012). Relationship between talent management and organizational success. International Research Journal of Applied and Basic Sciences, 3 (12), (pg. 2424-2430).

[20]. Salkey, J. (2005). Talent management for the 21 st century. Strategic HR Review, 4 (5), 2-2.

[21]. Sastry, N. S. (2013). HR Approaches to Talent Management. International Journal of Managerial Studies and Research, 1 (2), (pg. 34- 36).

[22]. Schehar Bano, M. A., \& Rehman, H. (2011). Study of the factors those impacts on talent management in the corporate sector of Islamabad, Pakistan. Far East Journal of Psychology and Business, 2 (1), (pg. 4-16).

[23]. Shafieian, G. (2014). Defining talent management components. Advanced Computational Techniques in Electromagnetics, (pg. 1-7).

[24]. Sheokand S, V. A. (2015). Talent Management: A Bird's Eye View. International Research Journal of Social Sciences, 4(2), (pg. 52-58).

[25]. Shuai Zhang, D. B. (2012). Talent definition 


\section{International Journal of Engineering Applied Sciences and Technology, 2019 \\ Vol. 4, Issue 5, ISSN No. 2455-2143, Pages 302-310 \\ Published Online September 2019 in IJEAST (http://www.ijeast.com)}

and talent management recognition in Chinese private-owned enterprises. Journal of Chinese Entrepreneurship, 4 (2), (pg. 143 - 163).

[26]. Snell, A. (2011). Developing talent intelligence to boost business performance. Strategic HR Review, 10 (2), (pg. 12-17).

[27]. Thota, V. k. (2013). Effective Talent Management Practices: A Strategy for Organizational Success. GRA- Global Research Analysis, 2 (11), (pg. 157-159).

[28]. Yapp, M. (2009). Measuring the ROI of talent management. Strategic HR Review, 8 (4), (pg. 5-10).

[29] Dr. Sarita Satpathy, P. SailajaRani, M.L.Nagajyothi, (2017)Study of Micro, Small and Medium Enterprises; the Backbone for Economic Development of Indian EconomyInternational Journal of Research and Scientific Innovation (IJRSI) | Volume IV, Issue VI, ISSN 2321-2705, (pg. 41-53) [30] Sheokand S, V.A. (2015). Talent Management: A Bird's Eye View. International Research Journal of Social Sciences, 4(2), (pg. 52-58).

[31] AbdulQuddus Mohammed, (2015). The Impact of Talent Management On employee engagement, Retention and Value Addition in achieving Organizational Performance. International Journal of Core Engineering and Management (IJCEM) Volume 1, Issue 12, (pg. 123-132).

[32] Chung, K. L. and D'Annunzio-Green, N. (2018). Talent Management practices of small and medium sized in the hospitality sector: an entrepreneurial owner manager perspective, Worldwide Hospitality and Tourism Themes, 10 (1), ISSN 1755-4217, (pg. 101-116)

[33] Miss. Shruti Ashok Naik (2012). Impact of talent management on the performance of an organization with social reference to ABG, Pipapar, Bharati Shipbuilding Industry, (pg. 12-28)

[34] John Musong Tusang and Dewi Tajuddin.'A Research on Talent Management Practices as a Strategy to Influence Employee Engagement and its Affect the Organization Performance'Australian Journal of Basic and Applied Sciences, 9(26) Special 2015, (Pg. 16-25).

[35] Dr. M. Kathiravan*, Dr. Saikumar V, Ms. V.Sunitha. Optimization Talent Management Process Analytics on Pharmaceutical SMEs Employees: Empirical Perspective.Int. J. Pharm. Sci. Rev. Res., 46(2), September - October 2017; Article No. 11, ISSN 0976 - 044X, (Pg. 52-59)

[36] Thunnissen, M. (2016). Talent management: For what, how and how well? An empirical exploration of talent management in practice. Employee
Relations, 38(1), (pg. 57-72). 